\title{
Modulation of the oxidative stress in malaria infection by clotrimazole
}

\author{
Juan Ricardo Rodrigues Henriques*, Neira Gamboa de Domínguez
}

\author{
Laboratory of Biochemistry, Faculty of Pharmacy, Central University of Venezuela, Caracas, Venezuela
}

\begin{abstract}
Antimycotic clotrimazole (CTZ) has demonstrated remarkable activity against Plasmodium falciparum in vitro and in vivo. Hemoglobin degradation by Plasmodium parasites makes amino acids available for protein synthesis, inducing oxidative stress in infected cells and producing free heme. These events represent biochemical targets for potential antimalarials. In this study, we have tested the ability of CTZ to modify the oxidative status in Plasmodium berghei-infected erythrocytes. After hemolysis, activities of superoxide dismutase (SOD), catalase (CAT), glutathione cycle and $\mathrm{NADPH}+\mathrm{H}^{+}$-producing dehydrogenases were investigated using UV-visible spectrophotometry. Thiobarbituric acid reactive substances (TBARS) were evaluated as a marker of lipid damage. Results showed that CTZ significantly decreased the overall activity of 6-phosphagluconate dehydrogenase (6PGD) compared to infected and non-treated cells; consequently, the glutathione cycle was inhibited, leaving the parasite vulnerable to the oxidative stress originating from hemoglobin degradation. As a compensatory response, CTZ prevented some loss of SOD and CAT activities in infected cells. The infection triggered lipid peroxidation in erythrocytes, which was decreased by CTZ. These results suggest the presence of a redox unbalance in cells treated with CTZ, discussing a possible effect of this compound disturbing the oxidative status in a Plasmodium berghei-infection.
\end{abstract}

Uniterms: $\beta$-Hematin. Clotrimazole/modulatory ability/oxidative stress. Oxidative stress. Plasmodium berghei. Eritrócitos infectados

O antifúngico clotrimazol (CTZ) tem demonstrado notável atividade contra Plasmodium falciparum. A degradação da hemoglobina por Plasmodium para a obtenção dos aminoácidos necessários à síntese protéica induz estresse oxidativo em eritrócitos devido à liberação de hemos oxidantes. Estes eventos representam alvos bioquímicos para a produção de antimaláricos potenciais. Neste estudo, testamos a capacidade do CTZ para modificar o estado oxidativo em eritrócitos infectados com Plasmodium berghei. Depois da hemólise, as atividades da superóxido dismutase (SOD), catalase (CAT), desidrogenases produtoras de $\mathrm{NADPH}+\mathrm{H}^{+}$e do ciclo de glutationa (GSH) foram investigados. A produção das espécies reativas ao ácido tiobarbitúrico (TBARS) foi avaliada como marcador de dano lipídico. Os resultados mostraram que o CTZ diminuiu a atividade da 6-fosfogliconato desidrogenase (6PGD), em comparação com eritrócitos infectados e não tratados. Consequentemente, o ciclo da GSH foi inibido, tornando os parasitas vulneráveis ao estresse oxidativo resultante da degradação da hemoglobina. Como resposta compensatória, CTZ impediu a perda de atividade da SOD e CAT nas células infectadas. A infecção induz peroxidação lipídica nos eritrócitos, sendo esta diminuída pelo CTZ. Estes resultados sugerem a existência de desequilíbrio redox nas células tratadas com CTZ, interferindo, assim, com o estado oxidativo verificado durante a infecção malárica.

Unitermos: $\beta$-Hematina. Clotrimazol/capacidade modulatória/estresse oxidativo. Estresse oxidativo. Plasmodium berghei. Eritrócitos infectados.

\footnotetext{
*Correspondence: J. R. R. Henriques. Laboratory of Biochemistry, Faculty of Pharmacy, Central University of Venezuela, 47206, 1051-A - Los Chaguaramos - Caracas, Venezuela. E-mail: juanricardorodrigues@gmail.com
} 


\section{INTRODUCTION}

Malaria is one of the more-frequently reported tropical disease worldwide. During 2008 alone, there were 247 million cases of malaria and nearly one million deaths, mostly among children living in Africa, accounting for $20 \%$ of all childhood deaths in that year (WHO 2008). Resistance to antimalarial therapies has grown in an alarming manner during the past years, undermining malaria control efforts. Thus, to fight against this increasingly-resistant infectious disease, developing alternative therapies is a priority.

Hemoglobin proteolysis in intraerythrocytic malaria parasites is a biochemical process that occurs in the acidic digestive vacuole of Plasmodium parasites by a group of proteases. This process provides free amino acids necessary for protein synthesis (Goldberg et al., 1990; Gamboa, Rosenthal, 1996). In this context, the oxidant heme group is separated from the globin chains in which $\mathrm{Fe}^{+2}$ is oxidized to form $\mathrm{Fe}^{+3}$, and the electrons produced react with molecular oxygen to form oxygen radicals (Francis et al., 1997; Atamna and Ginsburg, 1993; Mohan et al., 1992a). Parasites protect themselves from the deleterious effects of the free heme group by crystallizing part of the heme moieties into an insoluble non-toxic pigment called hemozoin or B-hematin (Francis et al., 1997; Bendrat et al., 1995). Meanwhile, the remainder of the heme moieties are detoxified by GSH-dependent degradation (Atamna and Ginsburg 2005). An alternative mechanism was proposed by Loria et al. (1999) which showed that hemoglobin oxidizes spontaneously due to the acidic environment of the digestive vacuole producing superoxide anion. This oxygen radical formation follows the production of $\mathrm{H}_{2} \mathrm{O}_{2}$ and the destruction of the porphyrin ring of the toxic heme.

Azole antimycotics have been reportedly acted as inhibitors of Plasmodium growth in culture and in vivo (Tiffert et al., 2000a; Raether and Seidenath, 1984; Rodrigues et al., 2011; Borhade et al., 2012). CTZ is exploited for its potential antimalarial effects by modifying the morphology of the parasites and through interference with its development and replication (Tiffert et al., 2000a). Moreover, this compound has been recently formulated in a nanoemulsion-based system with the aim of improving its solubility and dissolution, which can be further used in preclinical antimalarial evaluations (Borhade et al., 2011; Borhade et al., 2012). Also, a series of heterocyclic azole-based compounds were described as inhibitors of P. falciparum lactate dehydrogenase at micromolar concentrations, and these compounds displayed modest activity against parasitized erythrocytes, including parasite strains with known resistance to existing antimalarials and against Plasmodium berghei in BALB/c mice (Cameron et al., 2004).

Previous reports have shown that different compounds can modulate the oxidative status in infected erythrocytes. Quinoline compounds, such as chloroquine and dequalinium, can produce oxidative unbalance in parasitized erythrocytes in vitro (Ginsburg et al., 1998; Rodrigues, Gamboa 2009). Indeed, a recently synthesized indanoyl-quinoline also exhibited antiamalarial properties by the inhibition of NADPH $+\mathrm{H}^{+}$-dependent dehydrogenases, glutathione peroxidase and glutathioneS-transferase, inducing oxidative stress in infected red blood cells (Rodrigues et al., 2009). Also, the endoperoxide artemisinin is thought to react with heme moieties forming cytotoxic radicals producing a pro-oxidative environment, suggesting a mechanism of its antimalarial action (Becker et al., 2004).

In the search for new antimalarial compounds targeting different antioxidant pathways, we have evaluated the ability of CTZ to modify the antioxidant defence in Plasmodium berghei-infected red blood cells. Thus, a deregulation in the normal malaria oxidative status could be responsible for the antimalarial mechanism of action of this compound, in addition to its ability to inhibit host hemoglobin degradation recently reported in Rodrigues et al. (2011).

\section{MATERIAL AND METHODS}

\section{Drugs and animals}

CTZ (Figure 1) was provided by CALOX International, based in Caracas, Venezuela. For in vitro assays, the drug was prepared as a $100 \mathrm{mM}$ stock solution in dimethyl sulfoxide (DMSO) and stored at $4{ }^{\circ} \mathrm{C}$. All reagents were purchased at analytical grade from Sigma Company. Mice were housed under conditions approved by the Ethics Committee at the School of Pharmacy, Central

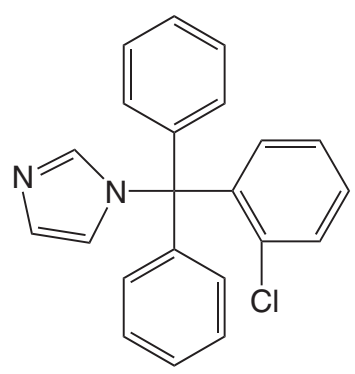

FIGURE 1 - Structure of the azole compound clotrimazole (CTZ). 
University of Venezuela (PG-CDCH- 06.30.5125-2007; FF-01032007).

\section{Experimental host and strain maintenance}

Male albino mice (BALB/c, 18-22 g) received a commercial pellet diet of Ratarina Protinal ${ }^{\circledR}$ (composition: proteins $26 \%$, fats $2 \%$, fibers $6 \%$, nitrogen-free extracts $40 \%$, vitamins A, B1, B12, D3, E, biotin, niacin, trace minerals $\mathrm{Co}, \mathrm{Cu}, \mathrm{Fe}, \mathrm{Mn}, \mathrm{I}$ and $\mathrm{Zn}$ ) and water ad libitum. Plasmodium berghei-ANKA was used for the infections. Mice were infected intraperitoneally with $10^{7}$ infected erythrocytes. Blood samples were removed when the animals reached $25 \%$ of parasitemia, and they were diluted in phosphate buffer solution (PBS $10 \mathrm{mM}, \mathrm{pH} 7.4,0.1 \mathrm{~mL}$ ). Parasitemia was monitored by microscopic examination of Giemsa stained smears.

\section{Incubation of erythrocytes with CTZ}

Non-infected erythrocytes $\left(1 \times 10^{9}\right)$ and Plasmodium berghei-infected erythrocytes from mice (2-3\% parasitemia and $4 \%$ hematocrit) were incubated in RPMI 1640 medium (pH 7.3) supplemented with $20 \%$ foetal calf serum in the presence of CTZ $(10 \mu \mathrm{M}$, large-scale cultures) (Janse, Waters 1995). After 24 hours of culture, non-treated infected erythrocytes mostly developed to the schizont stage, while the growth of treated (CTZ) and infected erythrocytes was arrested. Samples were centrifuged $\left(5000 \mathrm{~g} \times 10 \mathrm{~min} \times 4{ }^{\circ} \mathrm{C}\right)$, washed with saline solution and hemolyzed.

\section{Activities of superoxide dismutase (SOD) and catalase (CAT)}

To determine the activity of SOD, samples were hemolyzed with $0.4 \mathrm{vol}$ of chloroform/ethanol (1.5:1), and the activity was measured according to McCord and Fridovich (1969), which tracks the reduction of cytochrome $c$ at $550 \mathrm{~nm}$. For CAT activity, samples were hemolyzed with 4 vol of chilled water and diluted 1:500 with phosphate buffer ( $\mathrm{pH} 7.0)$ and activity was measured according to Aebi (1984), which tracks the reduction of $\mathrm{H}_{2} \mathrm{O}_{2}(30 \mathrm{mM})$ at $240 \mathrm{~nm}$. The results were expressed as the percentage of decrease in activity compared to non-infected and non-treated erythrocytes (control cells).

\section{Activities of dehydrogenase enzymes}

To determine the activities of glucose-6-phosphate dehydrogenase (G6PD), 6-phosphogluconate dehydrogenase (6PGD) and isocitrate dehydrogenase (ID), samples were lysed $(1: 10)$ with a stabilized solution $(5 \mu \mathrm{L}$ of $\beta$-mercaptoethanol, $1 \mathrm{~mL}$ of EDTA $10 \%$ and water to $100 \mathrm{~mL}, \mathrm{pH}$ 7.0). Measurements were determined according to Bergmeyer et al., (1974), King (1974) and Bernt and Bergmeyer (1974) respectively. The results were expressed as a percentage of activity compared to non-infected and non-treated erythrocytes (control cells).

\section{Glutathione cycle determinations}

Total glutathione (GSH + GSSG) from erythrocytes were detected according to a modification of Tietze (1969). In short, samples were lysed with stabilized solution $\mathrm{pH} 7.0(1: 10)$ and $1 \mathrm{vol}$ was added to $7 \mathrm{vol}$ of a mixture that contained phosphate buffer (PBS, $10 \mathrm{mM}$, $\mathrm{pH}$ 7.5), NADPH $+\mathrm{H}^{+}(0.2 \mathrm{mM})$ and dinitro-benzene (DTNB, $0.6 \mathrm{mM}$ ). After adding glutathione reductase $(10 \mu \mathrm{g} / \mathrm{mL})$ to the samples, the increase in optical density at $412 \mathrm{~nm}$ was recorded, representing the formation of the reduced product, thionitrobenzene. A standard curve of GSH $(0.02-200 \mu \mathrm{M})$ was done in parallel. To determine glutathione peroxidase (GPx) activity, samples were lysed with stabilized solution (1:10) and measurements were taken according to Paglia and Valentine (1967) with a modification made by Flohé and Günzler (1984), which register $\mathrm{NADPH}+\mathrm{H}^{+}$oxidation at $340 \mathrm{~nm}$. For glutathione $S$-transferase (GST) activity, samples were hemolyzed with stabilized solution (1:10) and measurements were taken according to Habig et al., (1974), which tracks the conjugation of 1-Cl-2,4-dinitro benzene (CDNB, $1 \mathrm{mM})$ with reduced glutathione $(5 \mathrm{mM})$ at 340 $\mathrm{nm}$. Results were expressed as a percentage of activity of the enzymes compared to non-infected and non-treated erythrocytes (control cells).

\section{Determination of erythrocyte lipid peroxidation}

To obtain membrane samples, erythrocytes were lysed through a treatment with $\operatorname{PBS}(5 \mathrm{mM} \mathrm{pH}=7.4)$ at $4{ }^{\circ} \mathrm{C}(1: 10)$. The hemolysate obtained was centrifuged $\left(20000 \mathrm{~g} \times 10 \mathrm{~min}\right.$ at $\left.4^{\circ} \mathrm{C}\right)$. Membrane pellets were washed three times with saline solution and stored at $-80^{\circ} \mathrm{C}$ for 24 hours.

Erythrocyte lipid peroxidation was determined by measuring thiobarbituric acid (TBA) reactivity according to Buege and Aust (1978). In short, membrane samples were mixed with phosphoric acid $10 \% \mathrm{p} / \mathrm{v}$ in $0.1 \mathrm{~N} \mathrm{HCl}$ $(1: 6)$ and TBA $(0.6 \% \mathrm{p} / \mathrm{v}$ in $0.1 \mathrm{~N} \mathrm{HCl})(1: 2)$. Samples were incubated in boiling water for 45 minutes and pretreated 
with butylated hydroxytoluene (BHT, $20 \mu \mathrm{M})$ to avoid TBARS-level overestimation. Malondyaldehyde (MDA), the main product of lipid peroxidation reacts with TBA to form a coloured complex that has a maximum absorbance at $532 \mathrm{~nm}$.

Protein levels were determined according to Lowry et al. (1951). Data were presented as the average of four independent experiments $(n=4)$ and tested for statistical significance using unpaired t-tests for specific group comparisons assuming 95\% confidence limits using GraphPad Prism 4.02 software.

\section{RESULTS}

The antioxidant system represent a main pathway to detoxify free radicals produced during hemoglobin metabolism in infected erythrocytes. Results of experiments on the main antioxidants in the presence of the azole compound CTZ are expressed in Figures 2 and 3 and in Table I.

Our results show that the activity of the first line of antioxidant defense was significantly decreased due to the infection, since the overall SOD and CAT activities diminished. This event may be responsible for the presence of oxidative stress in the infected cells. However, CTZ treatment prevented some loss of activity of the SOD and CAT compared to untreated and infected cells (Figure 2).

The infection also effected the activities of NADPH $+\mathrm{H}^{+}$-producing dehydrogenases (G6PD, 6PGLD and ID) showing significant increases in their activities compared to non-infected and untreated erythrocytes. This increase could be due to the high demand of this reducing co-factor during the infection. CTZ incubation resulted in a strong overall decrease in the activity of 6PGD in infected cells. This is one of the main enzymes of the hexose-monophosphate shunt, and it could represent a possible target for the antimalarial activity of new compounds (Figure 3 ).

The infection also led to increases in the overall activity of GST and in total glutathione levels, while no significant modifications were reported in GPx; however, CTZ decreased the activity of both enzymes (Table I), which could be due to the inhibition of one of the key enzymes of the hexose-monophosphate pathway by this compound. Plasmodium berghei infection promoted oxidative stress in infected cells, corroborated by higher levels of lipid peroxidation. CTZ did not over-produce lipid damage; we detected significant protection against lipid peroxidation (Figure 4).

\section{DISCUSSION}

Mechanisms of the antimalarial activity of CTZ have been proposed in relation to $\mathrm{Ca}^{+2}$ ions. This drug inhibits the sarcoplasmic reticulum $\mathrm{Ca}^{+2}$ pump, causing the depletion of intracellular $\mathrm{Ca}^{+2}$ stores (Tiffert et al., $2000 \mathrm{~b}$ ). This effect produces the activation of protein kinase $\mathrm{R}$ and phosphorylation of eukaryotic translation initiation factor $2 \alpha$, leading to the inhibition of protein synthesis in parasites (Aktas et al., 1998). However, our group has demonstrated that this antimycotic azole can

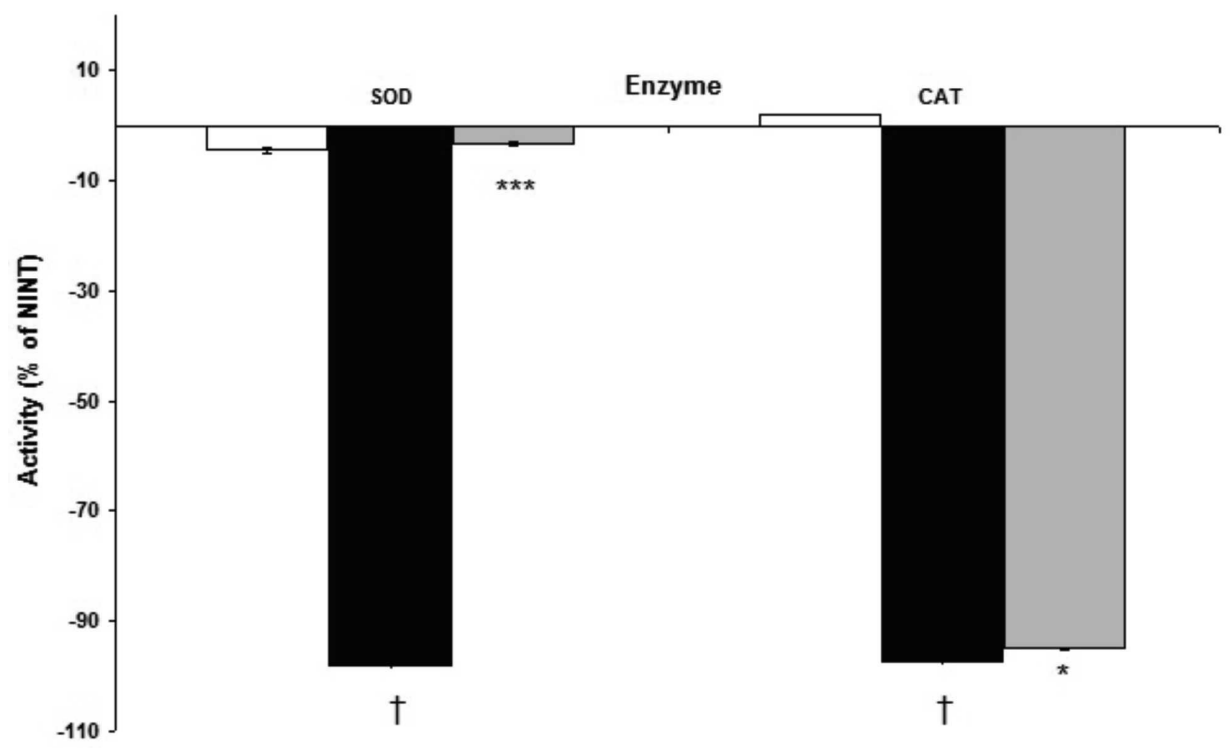

FIGURE 2 - The first line of the antioxidant defense enzymes in Plasmodium berghei-infected erythrocytes treated with clotrimazole (CTZ). Results are expressed as the mean \pm SEM of the percentage of activity compared to non-infected and non-treated erythrocytes (NINT) (basal line). SOD: superoxide dismutase; CAT: catalase; NI + CTZ: non-infected red blood cells and treated with CTZ (white bars); I: infected erythrocytes (black bars); I+CTZ: infected red blood cells and treated with CTZ (gray bars); ${ }^{\dagger} p<0.001$ compared to NINT; * $p<0.05$ and $* * * p<0.001$ compared to I. 


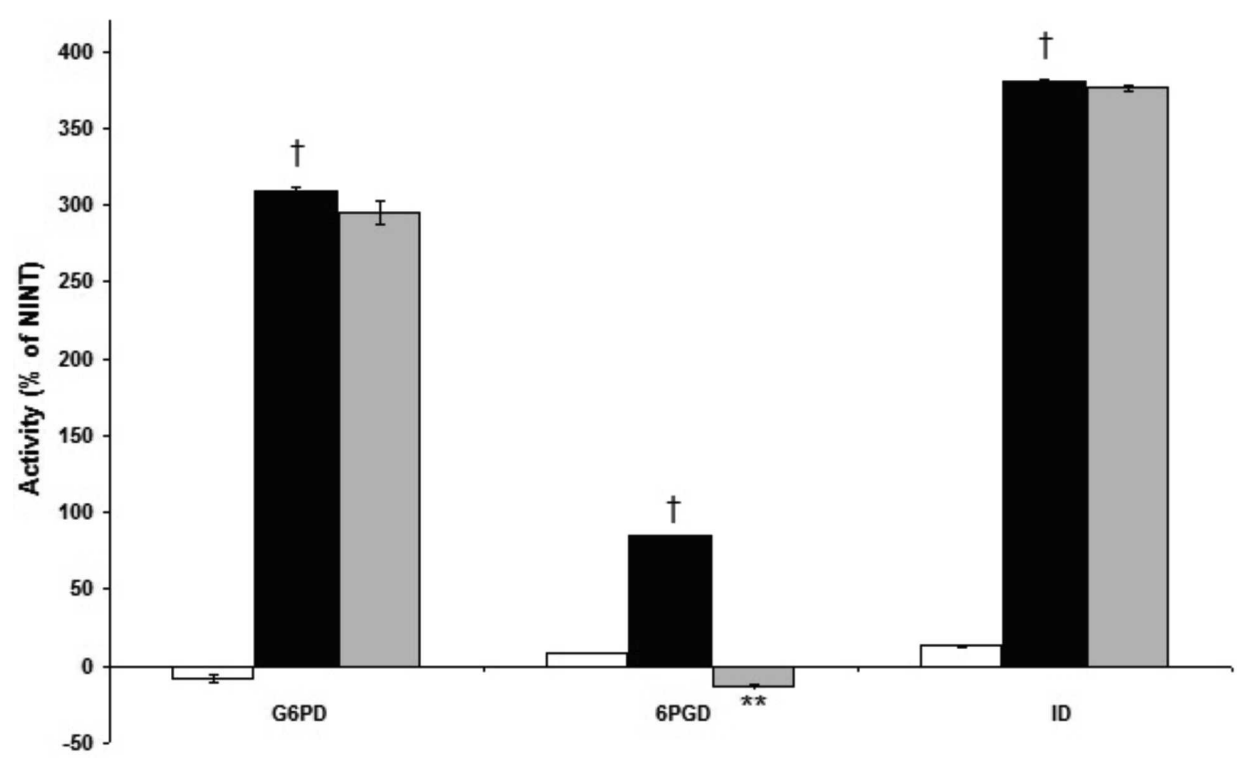

FIGURE 3 - NADPH $+\mathrm{H}^{+}$-producing dehydrogenase enzymes in Plasmodium berghei-infected erythrocytes treated with clotrimazole (CTZ). Results are expressed as the mean \pm SEM of the percentage of activity compared to non-infected and nontreated erythrocytes (NINT) (basal line). G6PD: glucose-6-phosphate dehydrogenase; 6PGD: 6-phosphogluconate dehydrogenase; ID: isocitrate dehydrogenase; NI + CTZ: non-infected red blood cells and treated with CTZ (white bars); I: infected erythrocytes (black bars); I+CTZ: infected red blood cells and treated with CTZ (gray bars); ${ }^{\dagger} p<0.05$ compared to NINT; ${ }^{* *} p<0.01$ compared to I.

TABLE I - Effect of clotrimazole (CTZ) on the glutathione cycle in Plasmodium berghei-infected erythrocytes

\begin{tabular}{lccc}
\hline Treatment & $\mathrm{GSH}+\mathrm{GSSG}\left(\mu \mathrm{mol} / \mathrm{mg} \times 10^{-3}\right)$ & $\mathrm{GPx}\left(\mathrm{U} / \mathrm{mg} \times 10^{-6}\right)$ & $\mathrm{GST}\left(\mathrm{U} / \mathrm{mg} \times 10^{-3}\right)$ \\
\hline $\mathrm{NI}$ & $10,18 \pm 0,93$ & $21,08 \pm 0,52$ & $40,37 \pm 2,76$ \\
$\mathrm{NI}+\mathrm{CTZ}$ & $10,25 \pm 1,16$ & $22,14 \pm 1,55$ & $39,321 \pm 2,05$ \\
$\mathrm{I}$ & $20,17 \pm 0,51^{* * *}$ & $18,39 \pm 1,6$ & $59,39 \pm 6,1^{\dagger}$ \\
$\mathrm{I}+\mathrm{CTZ}$ & $21,72 \pm 0,72$ & $10,15 \pm 1,67 * *$ & $18,54 \pm 1,38^{* *}$ \\
\hline
\end{tabular}

Results are expressed as the mean \pm SEM. NI: non-infected erythrocytes; I: infected erythrocytes; GSH: reduced glutathione; GSSG: oxidized glutathione; GPx: glutathione peroxidase; GST: glutathione $S$-transferase. ${ }^{\dagger} p<0.05 ;{ }^{* * *} p<0.001$ compared to NI; ${ }^{* *} p<0.01$ compared to I.

disturb hemoglobin metabolism in Plasmodium bergheiinfected erythrocytes through the inhibition of the heme crystallization, and this event could be responsible for its in vivo antimalarial actions (Rodrigues et al., 2011). Although, the effects of CTZ on the oxidative/antioxidative routes, a subsequent pathways of hemoglobin metabolism and heme detoxification in infected red blood cells, are not well known.

Plasmodium parasites degrade host hemoglobin through aspartic and cysteine proteases to provide amino acids for protein synthesis (Goldberg 1992). In this process, free toxic heme moieties crystallize spontaneously in the acid environment of the digestive vacuole to form an insoluble pigment called hemozoin or $\beta$-hematin (Orijh, Fitch, 1993). During this event, electrons are transferred from the ferrous ion of the heme to oxygen-producing free radicals, which, in consequence, could induce oxidative stress in infected cells (Becker et al., 2004). This may involve the interaction between the parasite and the host cell, thereby producing modifications in several systems, by which the oxidative characterization must include different parameters. In this study, we show that these variables are susceptible to the effects of CTZ.

The expression of CAT appears to be increased in Plasmodium falciparum-infected erythrocytes (Clarebout et al., 1998); however, the activity of this enzyme is decreased in Plasmodium berghei infection, which could rise the levels of $\mathrm{H}_{2} \mathrm{O}_{2}$, leading the formation of hydroxyl radicals (Areekul, Boonme, 1986; Mohan et al., 1992b, Rodrigues, Gamboa, 2009). Previous studies have also shown that the overall activity of SOD is decreased due to the infection in Plasmodium falciparum, Plasmodium knowlesi and Plasmodium berghei-infected cells (Farombi et al., 2003; Srivastava et al., 1992; Rodrigues et al., 


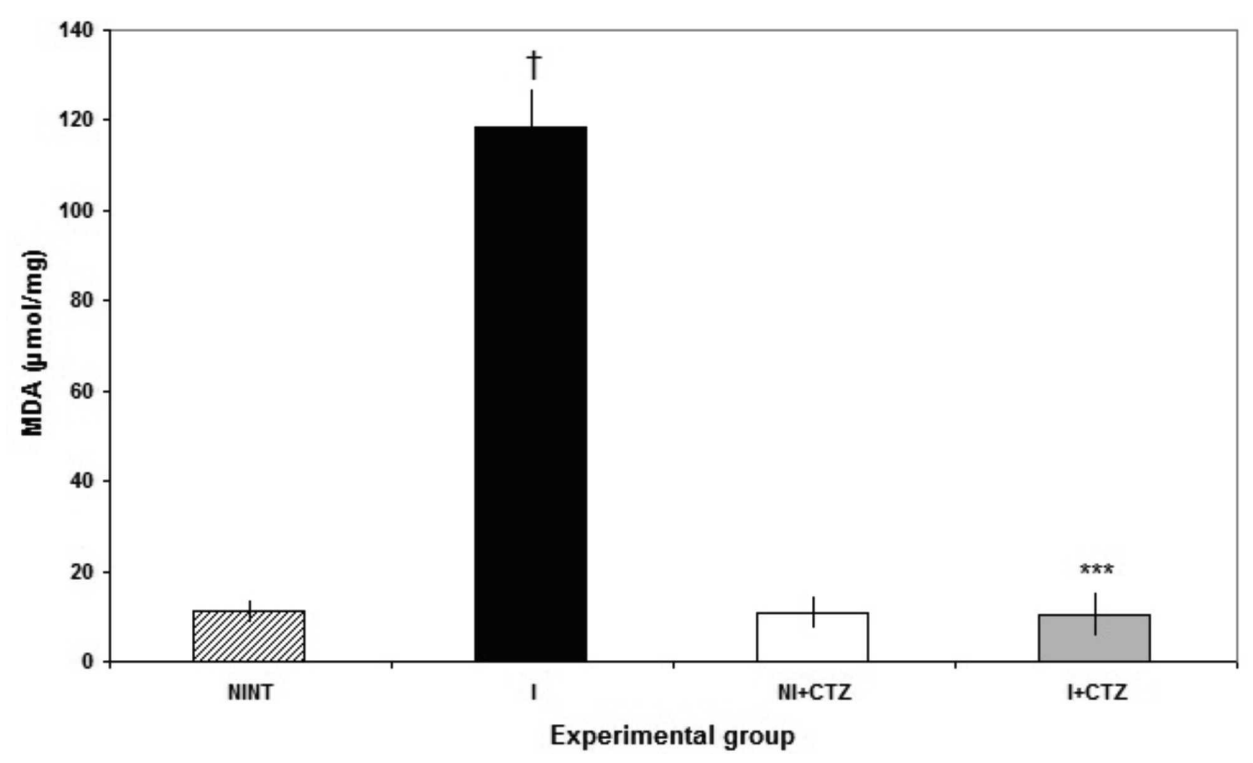

FIGURE 4 - Effect of clotrimazole (CTZ) on lipid peroxidation in Plasmodium berghei-infected erythrocytes. Results are expressed as the mean \pm SEM of MDA levels per mg of proteins. NINT: non-infected and non-treated erythrocytes; NI + CTZ: non-infected red blood cells and treated with CTZ; I: infected erythrocytes; I + CTZ: infected red blood cells and treated with CTZ. ${ }^{* * *} p<0.01$ compared I; ${ }^{\dagger} p<0.001$ compared to NINT.

2009). The activity loss of the first line of antioxidant enzymes could be due to their income from the erythrocyte cytoplasm to the digestive vacuole in the parasite via endocitosis (Francis et al., 1997; Ginsburg, Atamna, 1994). Indeed, in the acidic environment, the enzymes could be inactivated, which would increase the levels of free radicals in the infected-erythrocyte, promoting oxidative stress.

Our results are in concordance with reports cited previously, since we observed significant decreases in the overall activities of SOD and CAT in Plasmodium bergheiinfection, which could explain the oxidative stress and the perturbation in the erythrocyte antioxidant system observed in malarial disease. However, infected erythrocytes treated with CTZ prevented some loss of the activities of these enzymes compared to infected and untreated cells, confirming previous evidence in infected monkeys, mice treated with quinoline compounds, and in infected red blood cells, which could be due to a defense mechanism for the oxidative stress triggered by the infection (Srivastava et al., 1992; Rodrigues, Gamboa, 2009; Rodrigues et al., 2009).

Key enzymes G6PD, 6PGD and ID are responsible for producing NADPH $+\mathrm{H}^{+}$necessary for the adequate function of antioxidant cycles in red blood cells as thioredoxin and glutathione systems. We show that in Plasmodium berghei-infected erythrocytes there is an increase in all of the dehydrogenase enzymes tested, compared to non-infected cells, which confirms the increased metabolic flow through the hexose-monophosphate shunt during the infection (Roth et al., 1982; Rodrigues, Gamboa 2009).
In oxidative stress conditions, such as in Plasmodiuminfected cells, it is urgent to increase the NADPH $+\mathrm{H}^{+}$ levels used in the glutathione and thioredoxin cycles, therefore avoiding the deleterious effects of oxygen radicals. However, treatment with CTZ showed decreases in the overall activity of the hexose-monophosphate enzyme 6PGD, which could lead to a lower level of NADPH $+\mathrm{H}^{+}$ and promote a more sensitive state to oxidative stress in infected cells, as well as decrease the ability of erythrocytes to detoxify oxygen radicals, as previously reported by our group with chloroquine and other quinoline-related structures (Rodrigues, Gamboa, 2009; Rodrigues et al., 2009). This effect should be added to the antimalarial properties of this compounds and shows that these enzymes could represent new targets for antimalarial chemotherapy, as it has been demonstrated for some antimalarials against purified G6PD (Cotton, Sutorious 1971).

The glutathione cycle is one of the major systems for avoiding the deleterious effects of free radicals. GPx and GST are known to use GSH as a substrate. Total glutathione levels and the overall activity of GST were increased due to the infection, which could be due to a detoxification function needed by the increased presence of radical metabolites, such as $\mathrm{H}_{2} \mathrm{O}_{2}$ and lipid peroxidation products, while GPx was not significantly modified by the infection. CTZ decreased the overall activities of GPx and GST, and this inhibition could produce a more sensitive environment for parasites to develop oxidative stress linked to the hemoglobin degradation. Indeed, GPx inhibition follows an increase of $\mathrm{H}_{2} \mathrm{O}_{2}$ produced during 
the free heme detoxification (Loria et al., 1999). In this context, the endoperxide artemisinin generates free radicals in part through its ability to inhibit GPx Plasmodium falciparum-infected erythrocytes (Itarrat et al., 2003).

The inhibition of GST by this antimycotic could lead to important modifications in the detoxification system, promoting an increase in toxic metabolites, such as hemin and peroxides. Inhibitors of this enzyme are parasitotoxic per se and might also prevent other antimalarials from being conjugated to glutathione, which could be useful in a combinatory therapy (Becker et al., 2004). It is important to remark that this enzyme also displays GSH-dependent peroxidase activity with $\mathrm{H}_{2} \mathrm{O}_{2}$ (Harwaldt et al., 2002). Compounds that inhibit this enzyme would lead to an increase in this peroxide, which consequently would produce catalase activation as a compensatory response, as found in our results.

Further, $\mathrm{CTZ}$ produced alterations in the oxidative status by the possible decrease of $\mathrm{NADPH}+\mathrm{H}^{+}$due to the inhibited overall activity of 6PGD. Thus, the glutathione cycle would be compromised while SOD and CAT activities could be over-activated to cope with the oxidative burst originated from the inhibition of the hexose-monophosphate pathway and glutathione system. These effects could be responsible, at least in part, for the antimalarial activity recently reported for this compound (Rodrigues et al., 2011; Borhade et al., 2012).

On the other hand, CTZ has been reported as an inhibitor of the hemoperoxidase, increasing the accumulation of $\mathrm{H}_{2} \mathrm{O}_{2}$ through the production of heme-clotrimazole adducts and causing a subsequent development of oxidative stress in Plasmodium falciparum (Trivedi et al., 2005). This azole produces heme-induced hemolysis due to the inhibition of the glutathione-dependent heme degradation and not by lipid peroxidation, even though this oxidative event is present during the infection (Omodeo-Sale et al., 2003; Rodrigues, Gamboa 2009). It appears that the enhancement of heme-induced hemolysis by CTZ is a result of a colloid osmotic mechanism (Huy et al., 2002). The hydrophobicity and the large molecular size of the hemeclotrimazole complex may be key factors for the induction of this type of hemolysis (Huy et al., 2004). Indeed, our results show that this compound did not produce further lipid peroxidation. Instead, its levels were significantly decreased in infected cells treated with this compound.

\section{CONLUSIONS}

In this study, we show that CTZ modified the oxidative status in infected erythrocytes through the interference in the hexose-monophosphate and the glutathione cycle, which could lead to increases in the overall activity of the first line of antioxidant enzymes. These encouraging results suggest that the in vitro and in vivo antimalarial activity showed by CTZ could also be due to a mechanism of action based on the despair of the oxidative status in infected red blood cells.

\section{ACKNOWLEDGMENTS}

This study was supported by Consejo de Desarrollo Científico y Humanístico (CDCH), Central University of Venezuela (Grants PG-CDCH-06.30.5125-2007).

\section{REFERENCES}

AEBI, H. Catalase in vitro. Method Enzymol., v.103, p.121126, 1984.

AKTAS, H.; FLUCKIGER, R.; ACOSTA, J.A.; SALVAGE, J.M; PALAKURTHI, S.S.; HALPERIN, J.A. Depletion of intracellular $\mathrm{Ca}^{2+}$ stores, phosphorylation of eIF2alpha, and sustained inhibition of translation initiation mediate the anticancer effects of clotrimazole. P. Natl. Acad. Sci. USA, v.95, n.14, p.8280-8285, 1998.

AREEKUL, S.; BOONME, Y. Catalase activity in red cell and liver of mice infected with Plasmodium berghei. SE Asian J. Trop. Med., v.17, n.1, p.48-52, 1986.

ATAMNA, H.; GINSBURG, H. Origin of reactive oxygen species in erythrocytes infected with Plasmodium falciparum. Mol. Biochem. Parasit., v.61, n.2, p.231-241, 1993.

ATAMNA, H.; GINSBURG, H. Heme degradation in the presence of glutathione. J. Biol. Chem., v.270, n.42, p.24876-24883, 2005.

BECKER, K.; TILLEY, L.; VENNERSTROM, D.R.; ROGERSON, S.; GINSBURG, H. Oxidative stress in malaria parasite-infected erythrocytes: host-parasite interactions. Int. J. Parasitol., v.34, n.2, p.163-189, 2004.

BENDRAT, K.; BERGER, B.J.; CERAMI, A. Haem polymerization in malaria. Nature, v.378, n.6553, p.138139, 1995.

BERGMEYER, H.U.; GAWEHN, K.; GRASSL, M. Glucose-6phosphate dehydrogenase. In: BERGMEYER, H.U. (Ed.). Methods of enzymatic analysis. New York: Academic Press, 1974. v.2, p.458-459. 
BERNT, E.; BERGMEYER, H.U. Isocitrate dehydrogenase. In: BERGMEYER, H.U. (Ed.). Methods of Enzymatic Analysis. New York: Academic Press, 1974. v.2, p.624-631.

BORHADE, V.; PATHAK, S.; SHARMA, S.; PATRAVALE, $\mathrm{V}$. Clotrimazole nanoemulsion for malaria chemotherapy. Part I: Preformulation studies, formulation design and physicochemical evaluation. Int. J. Pharm., v.431, n.1-2, p.138-148, 2012.

BORHADE, V.; PATHAK, S.; SHARMA, S.; PATRAVALE, V. Clotrimazole nanoemulsion for malaria chemotherapy. Part II: Stability assessment, in vivo pharmacodynamic evaluations and toxicological studies. Int. J. Pharm., v.431, n.1-2, p.149-160, 2012.

BUEGE, J.A.; AUST, S.D. Microsomal lipid peroxidation. Method Enzymol., v.52, p.302-310, 1978.

CAMERON, A.; READ, J.; TRANTER, R.; WINTER, V.J.; SESSIONS, R.B.; BRAY, R.L.; VIVAS, L.; EASTON, A.; KENDRICK, H.; CROFT, S.L.; BARROS, D.; LAVANDERA, J.L.; MARTIN, J.J.; RISCO, F.; GARCÍAOCHOA, S.; GAMO, F.J.; SANZ, L.; LEON, L.; RUIZ, J.R.; GABARRÓ, R.; MALLO, A.; GOMEZ, F. Identification and activity of a series of azole-based compounds with lactate dehydrogenase-directed anti-malarial activity. $J$. Biol. Chem., v.279, n.30, p.31429-31439, 2004.

COTTON, D.W.K.; SUTORIUS, A.H.M. Inhibiting effect of some antimalarial substances on glucose-6-phosphate dehydrogenase. Nature, v.233, n.5316, p.197, 1971.

FAROMBI, E.O.; SHYNTUM, Y.Y.; EMEROLE, G.O. Influence of chloroquine treatment and Plasmodium falciparum malaria infection on some enzymatic and nonenzymatic antioxidant defense indices in humans. Drug Chem. Toxicol., v.26, n.1, p.59-71, 2003.

FLOHÉ, L.; GÜNZLER, W.A. Assays of glutathione peroxidase. Method Enzymol., v.105, p.114-121, 1984.

FRANCIS, S.E.; SULLIVAN JR., D.J.; GOLDBERG, D.E. Hemoglobin metabolism in the malaria parasite Plasmodium falciparum. Annu. Rev. Microbiol., v.51, p.97-123, 1997.

GAMBOA, N.D.; ROSENTHAL, P. Cysteine proteinase inhibitors block early steps in hemoglobin degradation by cultured malaria parasites. Blood, v.87, n.10, p.4448-4454, 1996.
GINSBURG, H.; FAMIN, O.; ZHANG, J.; KRUGLIAK, M. Inhibition of glutathione-dependent degradation of heme by chloroquine and amodiaquine as a possible basis for their antimalarial mode of action. Biochem. Pharmacol., v.56, n.10, p.1305-1313, 1998.

GOLDBERG, D.E.; SLATER, A.F.; CERAMI, A.; HENDERSON, G.B. Hemoglobin degradation in the malaria parasite Plasmodium falciparum: an ordered process in a unique organelle. P. Natl. Acad. Sci. USA, v.87, n.8, p.2931-2935, 1990.

GOLDBERG, D.E. Plasmodial hemoglobin degradation: and ordered pathway in a specialized organelle. Infect Agent Dis., v.1, n.4, p.207-211, 1992.

GREENWOD, B.; MUTABINGWA, T. Malaria in 2002. Nature, v.415, n.6872, p.670-678, 2002.

HABIG, W.H.; PABST, M.J.M; JAKOBY, W.B. Glutathione-STransferases. The first enzymatic step in mercapturic acid formation. J. Biol. Chem., v.249, n.22, p.7130-7139, 1974.

HARWALDT, P.; RAHLFS, S.; BECKER, K. Glutathione-Stransferase of the malarial parasite Plasmodium falciparum: characterization of a potential drug target. Biol. Chem., v.383, n.5, p.821-830, 2002.

HUY, N.T.; TAKANO, R.; HARA, S.; KAMEI, K. Enhancement of heme-induced membrane damage by the anti-malarial clotrimazole: the role of colloid-osmotic forces. Biol. Pharm. Bull., v.27, n.3, p.361-365, 2004.

HUY, N.T.; KAMEI, K.; YAMAMOTO, T.; KONDO, Y.; KANAORI, K.; TAKANO, R.; TAJIMA, K.; HARA, S. Clotrimazole binds to heme and enhances hemedependent hemolysis. Proposed antimalarial mechanism of clotrimazole. J. Biol. Chem., v.277, n.6, p.4152-4158, 2002.

ITTARAT, W.; SREEPIAN, A.; SRISARIN, A. Pathepchotivong, K. Effect of dihydroartemisinin on the antioxidant capacity of P. falciparum-infected erythrocytes. SE Asian J. Trop. Med., v.34, n.4, p.744-750, 2003.

JANSE, C.J.; WATERS, A.P. Plasmodium berghei: the application of cultivation and purification techniques to molecular studies of malaria parasites. Parasitol. Today, v.11, n.4, p.138-143, 1995. 
KING, J. 6-Phosphogluconate dehydrogenase. In: BERGMEYER, H.U., (Ed.). Methods of enzymatic analysis. New York: Academic Press, 1974. v.2, p.632-635.

LORIA, P.; MILLER, S., FOLLEY, M.; TILLEY, L. Inhibition of the peroxidative degradation of haem as the basis of action of chloroquine and other quinoline antimalarials. Biochem. J., v.339, n.2, p.363-370, 1999.

LOWRY, O.H.; ROSEBROUGH, N.J.; FARR, A.L.; RANDALL, R. Protein measurement with the Folin phenol reagent. J. Biol. Chem., v.193, n.1, p.265-275, 1951.

LUERSEN, K.; WALTER, R.D.; MULLER, S. Plasmodium falciparum-infected red blood cells depend on a functional glutathione de novo synthesis attributable to an enhanced loss of glutathione. Biochem. J., v.346, n.2, p.545-552, 2000 .

McCORD, J.M.; FRIDOVICH, I. Superoxide dismutase. An enzymic function for erythrocuprein (hemocuprein). J. Biol. Chem., v.244, n.22, p.6049-6053, 1969.

MOHAN, K.; GANGULY, N.K.; DUBEY, M.L.; MAHAJAN, R.C. Oxidative damage of erythrocyte infected with Plasmodium falciparum. An in vitro study. Ann. Hematol., v.65, n.3, p.131-134, 1992a.

MOHAN, K.; GANGULY, N.K.; DUBEY, M.L.; MAHAJAN, R.C. Plasmodium falciparum induced perturbations of the erythrocyte antioxidant system. Clin. Chim. Acta, v.209, n.1-2, p.19-26, 1992 b.

OMODEO-SALÈ, F.; MOTTI, A.; BASILICO, N.; PARAPINI, S.; OLLIARO, P.; TARAMELLI, D. Accelerated senescence of human erythrocytes cultured with Plasmodium falciparum. Blood, v.102, n.2, p.705-711, 2003.

ORIJH, A.U.; FITCH, C.S. Hemozoin production by Plasmodium falciparum: variation with strain and exposure to chloroquine. Biochim. Biophys. Acta, v.1157, n.3, p.270274, 1993.

PAGLIA, D.E.; VALENTINE, W.N. Studies on the quantitative and qualitative characterization of erythrocyte glutathione peroxidase. J. Lab. Clin. Med., v.70, n.1, p.158-169, 1967.
RAETHER, W.; SEIDENATH, H. Ketoconazole and other potent antimycotic azoles exhibit pronounced activity against Trypanosoma cruzi, Plasmodium berghei and Entamoeba histolytica in vivo. Z. Parasitenk., v.70, n.1, p.135-138, 1984.

RAYNES, K. Bisquinoline antimalarials: their role in malaria chemotherapy. Int. J. Parasitol., v.29, n.3, p.367-379, 1999.

RODRIGUES, J.; GAMBOA, N. Effect of dequalinium on the oxidative stress in Plasmodium berghei-infected erythrocytes. Parasitol. Res., v.104, n.6, p.1491-1496, 2009.

RODRIGUES, J.; CHARRIS, J.; DOMINGUEZ, J.; ANGEL, J.; GAMBOA, N. Modification of oxidative status in Plasmodium berghei-infected erythrocytes by E-2-chloro8-methyl-3-[(4'-methoxy-1'-indanoyl)-2'-methyliden]quinoline compared to chloroquine. Mem. I. Oswaldo Cruz, v.104, n.6, p.865-870, 2009.

RODRIGUES, J.; LOURENCO, D.; GAMBOA, N. Disturbance in hemoglobin metabolism and in vivo antimalarial activity of azole antimycotics. Rev. Inst. Med. Trop., v.53, n.1, p.25$29,2011$.

ROTH, E.F.; RAVENTOS-SUAREZ, C.; PERKINS, M.; NAGEL, R.L. Glutathione stability and oxidative stress in $P$. falciparum infection in vitro: responses of normal and G6PD deficient cells. Biochem. Bioph. Res. Co., v.109, n.2, p.355-362, 1982.

SRIVASTAVA, P.; PURI, S.K.; DUTTA, G.P.; PANDEY, V.C. Status of oxidative stress and antioxidant defences during Plasmodium knowlesi infection and chloroquine treatment in Macaca mulatta. Int. J. Parasitol., v.22, n.2, p.243-245, 1992.

TIETZE, F. Enzymatic method for quantitative determination of nanogram amounts of total and oxidized glutathione. Anal. Biochem., v.27, n.3, p.502-522, 1969.

TIFFERT, T.; GINSBURG, H.; KRUGLIAK, M.; ELFORD, B.; LEW, V. Potent antimalarial activity of clotrimazole in in vitro cultures of Plasmodium falciparum. P. Natl. Acad. Sci. USA, v.97, n.1, p.331-336, 2000a.

TIFFERT, T.; STAINES, H.M.; ELLORY, J.C.; LEW, V.L. Functional state of the plasma membrane $\mathrm{Ca}^{2+}$ pump in Plasmodium falciparum-infected human red blood cells. J. Physiol., v.525, n.1, p.125-134, 2000 b. 
TRIVEDI, V.; CHAND, P.; SRIVASTAVA, K.; MAULIK, P.R.; BANDYOPADHYAY, U. Clotrimazole inhibits hemoperoxidase of Plasmodium falciparum and induces oxidative stress. Proposed antimalarial mechanism of clotrimazole. J. Biol. Chem., v.280, n.50, p.41129-41136, 2005.
WORLD HEALTH ORGANIZATION (WHO). World Malaria Report 2008. Available at: <http://whqlibdoc.who.int/ publications/2008/9789241563697_eng.pdf>. Accessed on: 02 Aug 2009.

Received for publication on $17^{\text {th }}$ November 2011 Accepted for publication on $29^{\text {th }}$ May 2012 